\title{
Neonatal diarrhoea in calves given milk-substitutes differing in fat source: and fed by different procedures
}

\author{
BY M. ABE AND O. TAKASE \\ School of Veterinary Medicine, Azabu University, 1-17-71 Fuchinobe, \\ Sagamihara-shi 229, Japan \\ A.ND H. SHIBUI AND T. IRIKI \\ Laboratory of Nippon Formula Feed Manufacturing Co., 4-1-1 Higashiterao, \\ Tsurumi-ku, Yokohama 230, Japan
}

(Received 5 March 1981 - Accepted 29 June 1981)

1. The incidence of diarrhoea, digestibilities of nutrients and the faecal bacterial flora were compared among three groups of Holstein male calves up to 3 weeks of age. Two groups of four calves were given a milk-substitute containing tallow by nipple-pail (group TN) and by open-bucket (group TB). The third group of four calves was nipple-fed a milk-substitute containing soya-bean oil (group SN). Each of the milk-substitutes contained approximately $300 \mathrm{~g}$ milk-protein and $100 \mathrm{~g}$ fat $/ \mathrm{kg}$ dry matter (DM).

2. Mean faecal DM contents $(\mathrm{g} / \mathrm{kg}$ ) were 217,185 and 112 for groups TN, TB and SN respectively and the corresponding $\mathrm{pH}$ values were $7 \cdot 21,7.00$ and 6.50 . The difference between groups TN and SN was statistically significant $(P<0.05)$.

3. No difference was observed between groups TN and SN in the apparent digestibilities of DM, crude protein (CP; nitrogen $\times 6.25$ ), diethyl ether extract (EE) and total reducing sugars. But in the group TB, the digestibility of EE was significantly lower $(P<0.05)$, and that of $\mathrm{CP}$ tended to be, though not significantly, lower than in the other two groups.

4. Bacterial flora in faeces showed considerably wide quantitative variations among individual calves, but there was a tendency for increased viable counts of Lactobacilli in faeces of group SN.

5. The present results suggested that an appreciable difference in the mechanism would exist between diarrhoea occurring when milk-substitute was offered by bucket and when highly-unsaturated vegetable oils were contained in it. Possible mechanisms were also discussed.

In general the incidence of diarrhoea is higher in calves given a milk-substitute than in those receiving whole milk. The etiology of diarrhoea resulted from feeding a milk-substitute is quite manifold, since many' nutritional factors are responsible for it.

In Japan milk-substitutes are usually fed by bucket rather than by nipple-pail, because of simplicity. Compared with nipple-feeding, bucket-feeding resulted in faster rates of drinking a liquid milk-substitute, resulting in a more rapid passage through the abomasum and the lower gut probably due to less efficient coagulation in the abomasum (Abe et al. 1979). There is a reduction in proteolytic activity in the abomasum of bucket-fed calves (Grosskopf, 1959). Less efficient clotting of milk-protein as well as reduced gastric proteolysis may affect the incidence of diarrhoea in calves receiving a milk-substitute, since these factors are responsitle for the increased concentration of undigested or partiallydigested proteins in the small intestine, resulting in a shift of bacterial flora in this region (Weijers \& van de Kamer, 1965; Ternouth \& Roy, 1978). Wise \& La Master (1968) observed that bucket-feeding of whcle milk at a level greater than $140 \mathrm{~g} / \mathrm{kg}$ live weight resulted in a high incidence and persistence of diarrhoea in calves aged 3-4 weeks.

It is also known that highly unsaturated vegetable oils often increase the incidence of diarrhoea when used as an energy source in milk-substitutes for young calves (Gullickson et al. 1942; Jacobson et al. 1949; Hopkins et al. 1959). However, the mechanism of diarrhoea in this instance is somewhat unclear. It has been shown that unsaturation of fat tends to 
Table 1. Composition and component of the milk-substitutes used in the experiment

\begin{tabular}{|c|c|c|}
\hline & \multicolumn{2}{|c|}{ Milk-substitute containing } \\
\hline & Tallow & Soya-bean oil \\
\hline \multicolumn{3}{|l|}{ Ingredients $(\mathrm{g} / \mathbf{k g})$} \\
\hline Skim milk & 867 & 867 \\
\hline Fat premix $A^{*}$ & 120 & - \\
\hline Fat premix B十 & - & 120 \\
\hline Sodium phosphate & 5 & 5 \\
\hline Vitamin premix $\ddagger$ & 4 & 4 \\
\hline Trace mineral premix $\S$ & 2 & 2 \\
\hline Chromic oxide & 2 & 2 \\
\hline \multicolumn{3}{|l|}{$\begin{array}{l}\text { Chemical composition } \\
\text { (g/kg dry matter (DM)) }\end{array}$} \\
\hline DM $(\mathrm{g} / \mathrm{kg})$ & 933 & 922 \\
\hline Crude protein (nitrogen $\times 6.25$ ) & 305 & 314 \\
\hline Diethyl ether extract & 99 & 97 \\
\hline Total reducing sugars & 454 & 475 \\
\hline Ash & 80 & 83 \\
\hline
\end{tabular}

* Contained $800 \mathrm{~g}$ tallow (homogenized and stabilized) $/ \mathrm{kg}$.

$\dagger$ Contained $800 \mathrm{~g}$ soya-bean oil (homogenized and stabilized) $/ \mathrm{kg}$.

† Contained (/kg): $150 \mathrm{mg}$ retinol, $2.5 \mathrm{mg}$ cholecalciferol, $50 \mathrm{~g}$ DL- $\alpha$-tocopheryl acetate.

$\S$ Contained $(\mathrm{g} / \mathrm{kg}): 320 \mathrm{KCl}, 240 \mathrm{MgSO}_{4} \cdot 7 \mathrm{H}_{2} \mathrm{O}, 80 \mathrm{Na}_{2} \mathrm{SO}_{4}, 30 \mathrm{FeSO}_{4} \cdot 7 \mathrm{H}_{2} \mathrm{O}, 28 \mathrm{ZnSO}_{4} .7 \mathrm{H}_{2} \mathrm{O}, 8 \mathrm{MnCO}_{3}$, $2 \mathrm{KI}, 290 \mathrm{CaCO}_{3}$.

improve its digestibility in rats and calves (Mattson, 1959; Radostits \& Bell, 1968), and that unsaturated fatty acids tend to be absorbed more efficiently in young calves than saturated acids of the same chain-length (Ma et al. 1964). Recently, in a comparison of calves given milk-substitutes containing butter fat, lard or maize oil, Gaudreau \& Brisson (1978) could find no appreciable difference in either the passage rate through the abomasum or gastric proteolysis, though the faecal dry matter (DM) content was markedly lower for the milk-substitute containing maize oil than for the other two fat sources.

The objective of the present work was to examine the mechanism of neonatal diarrhoea resulting from feeding a milk-substitute by bucket or feeding a milk-substitute containing a vegetable oil as an energy source, by comparing some of the factors responsible for the occurrence of diarrhoea in both instances.

\section{EXPER I MENT A L}

Animals and feeding

From twenty-six Holstein male calves purchased at 1 week of age, twelve healthy calves were selected and divided into three groups of four calves each. Two groups were offered a milk-substitute containing tallow as an energy source by nipple-pail (group TN) and open-bucket (group TB). The remaining group, SN, was given a milk-substitute containing soya-bean oil instead of tallow by nipple-pail. The composition of the milk-substitutes is shown in Table 1. Calves were given $400 \mathrm{~g}$ milk-substitute/d in two feeds at 08.30 and 16.30 hours after dissolving one part by weight milk-substitute in 8 parts warm water. No additional feeds, water or medicine, including antibiotics, were given during the 2-week experimental period. 
Table 2. Dry matter (DM) content of faeces, faecal $\mathrm{pH}$, and the daily excretion of volatile fatty acids (VFA) into faeces of calves given milk-substitutes containing different fat sources and fed by different procedures

(Meen values with their standard errors for four calves)

\begin{tabular}{|c|c|c|c|c|c|c|c|c|}
\hline \multirow[b]{3}{*}{ Group } & \multirow{3}{*}{$\begin{array}{l}\text { Fat source of } \\
\text { milk-substitute }\end{array}$} & \multirow{3}{*}{$\begin{array}{l}\text { Feeding } \\
\text { procedure }\end{array}$} & \multicolumn{6}{|c|}{ Faecal } \\
\hline & & & \multicolumn{2}{|c|}{$\underset{(\mathrm{g} / \mathrm{kg})}{\mathrm{DM}}$} & \multicolumn{2}{|c|}{$\mathrm{pH}$} & \multicolumn{2}{|c|}{$\underset{(\mathrm{mmol} / \mathrm{d})}{\mathrm{VFA}}$} \\
\hline & & & Mean & $\mathbf{S E}$ & Mean & SE & Mean & SE \\
\hline TN & Tallow & By nipple & $217^{\mathrm{s}}$ & 15 & $7 \cdot 21^{\mathrm{a}}$ & 0.08 & $116^{\mathrm{a}}$ & 11 \\
\hline TB & Tallow & By bucket & $185^{\mathrm{a}, \mathrm{b}}$ & 34 & $7.00^{\mathrm{a}, \mathrm{b}}$ & 0.03 & $109^{\mathrm{a}}$ & 17 \\
\hline SN & Soya-bean oil & By nipple & $112^{\mathrm{b}}$ & 19 & $6.50^{\mathrm{b}}$ & 0.23 & $196^{\mathrm{b}}$ & 28 \\
\hline
\end{tabular}

a, b, Mean values with different subscript letters in the same column differed significantly $(P<0.05)$.

\section{Digestibility}

The apparent digestibilities of the constituents of the milk-substitutes were measured by the total collection of faeces excreted in the last $4 \mathrm{~d}$ of experiment. As is shown in Table 1, chromic oxide was contained in the experimental milk-substitutes to make provision against the possible failure in the total collection of faeces, particularly in case of diarrhoea. In the circumstances, however, this was not necessary in this experiment.

\section{Diarrhoea}

The DM content of faeces collected during the last $4 \mathrm{~d}$ of experiment was used as a measure of the severity of diarrhoea. Faeces with DM contents over $200 \mathrm{~g} / \mathrm{kg}$ were considered normal, those values under $120 \mathrm{~g} / \mathrm{k}$ g were diarrhoeic, and intermediate values were 'loose' (Gaudreau \& Brisson, 1978).

\section{Bacterial flora in faeces}

Viable counts of Escherichia coli, Clostridia and Lactobacilli in faeces were measured using differential media (Mitsuoka, 1980). E. coli was cultured aerobically with DHL (deoxycholate hydrogen sulphide lactate'; agar at $37^{\circ}$ for $18 \mathrm{~h}$. Clostridia and Lactobacilli were cultured with CW (Clostridium welchii agar; Nissui Ltd, Toshima-ku, Tokyo) and LBS (Lactobacillus selective agar; BBL, Cokeysville, USA) respectively at $37^{\circ}$ for $48 \mathrm{~h}$ under an anaerobic condition produced by the steel-wool method (Kosakai \& Suzuki, 1968). All counts were the mean of two measurements on the 12th and the last day of the experiment.

\section{Analyses}

Total reducing sugars in the milk-substitutes and faeces were colorimetrically determined at $630 \mathrm{~m} \mu$ using anthrone seagent after hydrolysis with $0.75 \mathrm{M}$-hydrochloric acid for $2.5 \mathrm{~h}$. Faecal contents of volatile fatty acids (VFA) were determined by the distillation procedure (Kumeno \& Nishimatsu, 1963).

The results were subjected to analysis of variance, and the statistical significance of the differences between means were determined by Tukey's multiple range test (Yoshida, 1975).

\section{RESULTS}

The faecal DM content, $\mathrm{pH}$ of faeces, and the daily excretion of VFA into faeces are shown in Table 2. In group TN, faeces were almost normal except for one calf which excreted 
Table 3. Apparent digestibilities in calves given milk-substitutes containing different fat sources and fed by different procedures

(Mean values with their standard errors for four calves)

\begin{tabular}{|c|c|c|c|c|c|c|c|c|}
\hline \multirow[b]{2}{*}{ Group* } & \multicolumn{2}{|c|}{ Dry matter } & \multicolumn{2}{|c|}{$\begin{array}{l}\text { Crude protein } \\
\text { (nitrogen } \times 6.25 \text { ) }\end{array}$} & \multicolumn{2}{|c|}{$\begin{array}{l}\text { Diethyl } \\
\text { ether extract }\end{array}$} & \multicolumn{2}{|c|}{$\begin{array}{l}\text { Total } \\
\text { reducing sugars }\end{array}$} \\
\hline & Mean & SE & Mean & SE & Mean & SE & Mean & SE \\
\hline TN & 0.917 & 0.018 & 0.891 & 0.031 & $0 \cdot 860^{\mathrm{a}}$ & 0.030 & 0.974 & 0.007 \\
\hline TB & 0.876 & 0.015 & 0.820 & 0.037 & $0.732^{b}$ & 0.036 & 0.974 & 0.006 \\
\hline $\mathbf{S N}$ & 0.907 & 0.005 & 0.868 & 0.015 & $0.890^{8}$ & 0.018 & 0.970 & 0.003 \\
\hline
\end{tabular}

a, b, Mean values with different subscript letters in the same column differed significantly $(P<0.05)$.

TN, milk-substitute containing tallow fed by nipple-pail; TB, milk-substitute containing tallow fed by bucket; SN, milk-substitute containing soya-bean oil fed by nipple-pail.

- For details, see Table 2 and p. 544.

Table 4. Faecal viable counts (no./g faecal dry matter) of some bacteria in calves given milk-substitutes containing different fat sources and fed by different procedures

(Range of values for four calves)

\begin{tabular}{cccc}
\hline \hline Group* & Escherichia coli & Clostridia & Lactobacilli \\
\hline TN & $3.6 \times 10^{3}-4.6 \times 10^{7}$ & $<10^{8}$ & $2.7 \times 10^{8}-3.5 \times 10^{8}$ \\
TB & $6.9 \times 10^{4}-7.3 \times 10^{7}$ & $<10^{8} \dagger$ & $3.7 \times 10^{8}-5.1 \times 10^{8}$ \\
SN & $3.0 \times 10^{4}-2.5 \times 10^{8}$ & $<10^{8} \ddagger$ & $3.0 \times 10^{8}-1.3 \times 10^{10}$ \\
\hline
\end{tabular}

TN, milk-substitute containing tallow fed by nipple-pail; TB, milk-substitute containing tallow fed by bucket; SN, milk-substitute containing soya-bean oil fed by nipple-pail.

* For details, see Table 2 and p. 544.

$\dagger$ Less than $10^{2}$ in two calves, and $5.3 \times 10^{3}$ and $1.1 \times 10^{6}$ in the other two calves.

‡Less than $10^{2}$ in two calves, and $1.7 \times 10^{4}$ and $2.5 \times 10^{6}$ in the other two calves.

'loose' faeces, and the mean DM content in this group corresponded to the normal level. In contrast, faeces were almost diarrhoeic in group SN except for one calf which excreted 'loose' faeces, and the mean DM content was significantly lower than that of group TN $(P<0.05)$ and corresponded to the diarrhoeic level. In group TB, two calves were normal, one was 'loose', and one severely diarrhoeic. The mean faecal DM content of this group was intermediate between values for groups TN and SN, corresponding to the 'loose' level. The mean faecal pH in each group had a tendency identical to that of the mean DM content. It was significantly lower in group SN than in group TN $(P<0.05)$, and intermediate in group TB. The daily excretion of VFA in faeces was significantly greater in group SN than in the other two groups $(P<0.05)$.

Apparent digestibilities measured by the total faecal collection method are shown in Table 3. There was no significant difference in these values between groups TN and SN. However, the digestibility of diethyl ether extract (EE) was significantly lower $(P<0.05)$, and that of crude protein (CP; nitrogen $\times 6.25$ ) tended to be lower, though not significantly, in group TB than in the other two groups.

Table 4 shows the viable counts of $E$. coli, Clostridia and Lactobacilli in faeces excreted by calves in the three groups. There was a wide variation in viable counts of $E$. coli within each group and no consistent trend was observed among groups. The viable count of 
Clostridia was less than $10^{2} / \mathrm{g}$ faecal DM in all four calves in group TN and in two calves each in groups TB and $\mathrm{SN}$, but showed an increase of up to $10^{6}$ in two calves in both groups TB and SN. The viable count of Lactobacilli was within a range of $10^{8}-10^{\circ} / \mathrm{g}$ faecal DM in groups TN and TB, but was in the range $10^{\circ}-10^{10} / \mathrm{g}$ faecal DM in group SN. These results suggest that both the procedure for feeding the milk-substitute and its fat source would affect the intestinal bacterial flora. The tendency for an increase in the viable count of Lactobacilli in group $\mathrm{SN}$ was particularly noteworthy.

\section{DISCUSSION}

In accordance with the re:sults of many other workers (Gullickson et al. 1942; Jacobson et al. 1949; Hopkins et al. 1959), the inclusion of a highly-unsaturated vegetable oil in the milk-substitute caused a definite increase in the incidence and persistence of diarrhoea in calves up to 3 weeks of age. Also, bucket-feeding of the milk-substitute had a laxative effect on faeces when compared with nipple-feeding. However, there seemed to be some difference in the mechanism of diarrhoea occurring when the milk-substitute was fed by bucket and when vegetable oils were included in it. In our previous work (Abe et al. 1979), the rate of passage of the milk-substitute through the abomasum and the lower gut was higher when it was offered by bucket than when offered by nipple-pail. On the other hand, Gaudreau \& Brisson (1978) reported that the rate of passage through the abomasum was affected little by the fat source of milk-substitutes. In the present study, the incidence of diarrhoea appeared to be lower in sucket-fed calves than when calves received a milk-substitute containing soya-bean oil. Furthermore, a significant depression in the digestibility of EE was caused by bucket-feeding, but such a depression was not apparent in any of the constituents when the milk-substitute containing soya-bean oil was fed by nipple-pail.

Roy (1969) and Radostits \& Bell (1970) attributed neonatal diarrhoea of nutritional origin to an imbalance in the intestinal bacterial flora and classified it into either fermentative or putrefactive diarrhoea according to the qualitative and quantitative changes in bacterial flora. These authors suggested that fermentative diarrhoea would occur when the saccharolytic flora, consisting chiefly of Lactobacilli which produce low-molecular-weight organic acids and lactic acid, becorne predominant in the intestine. Whereas putrefactive diarrhoea was assumed to result from an abnormal multiplication of saccharoproteolytic flora, consisting chiefly of $E$. coi $i$ and Clostridia, which will produce excess amounts of amines and toxins as a result of the putrefaction of peptides and proteins. It has been also suggested that faeces in fermentative diarrhoea become acid, while those in putrefactive diarrhoea are usually alkaline (Radostits \& Bell, 1970).

In the present study, a tendency for an increase in the viable count of Lactobacilli, a significant fall in $\mathrm{pH}$, and also a significant increase in the excretion of VFA in faeces were observed in group SN which was given milk-substitute containing soya-bean oil by nipple-pail. These results do not contradict the mechanism of fermentative diarrhoea proposed by Roy (1969) and Radostits \& Bell (1970), suggesting that the diarrhoea in this instance was essentially formentative. However, it is uncertain whether bucket-feeding results in putrefactive diarrhoea, since no increase in faecal $\mathrm{pH}$ was observed in the present study. An increase in the faecal viable counts of Clostridia was observed in two calves of group TB, but a similar trend was also found in group SN.

When calves received the milk-substitute by bucket, a significant depression in digestibility was detected in EE, but not in CP. It has been reported that bucket-feeding results not only in a reduction in gastric proteolysis but also in a lower secretion of saliva and salivary lipase (EC 3.1.1.3) when compared to nipple-feeding (Wise et al. 1968). The decreased digestibility of EE observed in the present study for bucket-fed calves may, therefore, be due to the reduced secretion of salivary lipase. 
In summary, it is possible that the method of feeding the milk-substitute could influence the occurrence of diarrhoea in young calves, though the extent of this effect was relatively lower than the effect of including vegetable oils as a fat source. Diarrhoea resulting from bucket-feeding had characteristics which differed from those of diarrhoea caused by feeding a milk-substitute containing vegetable oils, and the latter seemed to be a fermentative diarrhoea as suggested by previous workers (Roy, 1969; Radostits \& Bell, 1970). With respect to the mechanism of diarrhoea in the former instance, however, there remains a need for further studies, especially in the relationship between the depression in fat hydrolysis and the occurrence of diarrhoea. In addition, more detailed studies will be necessary to explain why the inclusion of highly-unsaturated vegetable oils in milk-substitute give rise to diarrhoea of a fermentative nature.

The authors are indebted to Dr K. Suzuki for his helpful advice in the measurement of bacterial counts in faeces, and to Messrs N. Matsumura, T. Kawai and S. Kodama for their technical assistance. They also thank Riken Vitamin Ltd (Tokyo) for producing and furnishing the spray-dried fat premixes used for the preparation of milk-substitutes.

\section{REFERENCES}

Abe, M., Iriki, T., Kondoh, K. \& Shibui, H. (1979). Br. J. Nutr. 41, 175.

Gaudreau, J. M. \& Brisson, G. J. (1978). J. Dairy Sci. 61, 1435.

Grosskopf, J. F. W. (1959). Onderstepoort J. vet. Res. 32, 154.

Gullickson, T. W., Fountain, F. C. \& Fitch, J. B. (1942). J. Dairy Sci. 25, 117.

Hopkins, D. T., Warner, R. G. \& Loosli, J. K. (1959). J. Dairy Sci. 42, 1815.

Jacobson, N. L., Cannon, C. Y. \& Thomas, B. H. (1949). J. Dairy Sci. 32, 429.

Kosakai, N. \& Suzuki, S. (1968). Anaerobes in Clinical Medicine, lst ed. Tokyo: Igaku Shoin.

Kumeno, F. \& Nishimatsu, I. (1963). Jap. J. Zootech. Sci. 34, 207.

Ma, A. P., Hotchins, D. K. \& Allen, R. S. (1964). J. Dairy Sci. 47, 703.

Mattson, F. H. (1959). J. Nutr. 69, 338.

Mitsuoka, T. (1980). A Color Atlas of Anaerobic Bacteria, Ist ed. Tokyo: Sobunsha.

Radostits, O. M. \& Bell, J. M. (1968). Can. J. Anim. Sci. 48, 293.

Radostits, O. M. \& Bell, J. M. (1970). Can. J. Anim. Sci. 50, 405.

Roy, J. H. B. (1968). Proc. Nutr. Soc. 28, 160.

Ternouth, J. H. \& Roy, J. H. B. (1978). Br. J. Nutr. 40, 553.

Weijers, H. A. \& van de Kamer, J. H. (1965). Nutr. Abst. Rev. 35, 591.

Wise, G. H. \& La Master, J. P. (1968). J. Dairy Sci. 51, 452.

Wise, G. H., Miller, P. G., Anderson, G. W. \&ohns, J. C. (1968). J. Dairy Sci. 51, 737.

Yoshida, M. (1975). Design of Experiments for Animal Husbandry. 1st ed. Tokyo: Yokendo. 